\title{
A new fire resistant light mineral wool
}

\section{Journal Article}

\section{Author(s):}

Frangi, Andrea; Schleifer, Vanessa; Hugi, Erich

Publication date:

2012-07

Permanent link:

https://doi.org/10.3929/ethz-b-000041033

\section{Rights / license:}

In Copyright - Non-Commercial Use Permitted

\section{Originally published in:}

Fire Technology 48(3), https://doi.org/10.1007/s10694-010-0209-2 


\title{
A New Fire Resistant Light Mineral Wool
}

\author{
Andrea Frangi* and Vanessa Schleifer, ETH Zurich, Institute of Structural \\ Engineering, 8093 Zurich, Switzerland \\ Erich Hugi, Empa, Swiss Federal Laboratories for Materials Science \\ and Technology, 8600 Duebendorf, Switzerland
}

Received: 17 June 2010/Accepted: 23 December 2010/Published online: 11 January 2011

\begin{abstract}
A comprehensive research project on the fire performance of a new light mineral wool has been carried out at ETH Zurich in collaboration with the Swiss Federal Laboratories for Materials Science and Technology (EMPA). A large number of small-scale fire tests permitted the analysis of different parameters on the fire performance of the new mineral wool. The results of the fire tests allowed the verification and calibration of thermal properties used for thermal finite element (FE) analysis. Based on an extensive FE parametric study, the coefficients for the new mineral wool to be used in the design model for the verification of the separating function of light timber frame wall and floor assemblies were calculated. The paper first describes the main results of the experimental and numerical analyses. Then, the calculation of the coefficients for the new mineral wool to be used in the design model are presented.
\end{abstract}

Keywords: Fire tests, Mineral wool, Glass wool, Stone wool, Fire resistance, Start of charring, Insulation value, Separating function, Timber frame

\section{Introduction}

Due to the introduction of compulsory thermal insulation in most European countries, the use of insulation materials has increased, both in terms of buildings being insulated and in the minimum values of insulation required by the national regulations. The European market of insulating materials is characterised by the domination of inorganic fibrous materials, glass wool and stone wool, which account for $60 \%$ of the market, and organic foamy materials, expanded and extruded polystyrene and to a lesser extent polyurethane, which account for some $27 \%$ of the market [1]. Glass wool consists of quartz sand, dolomite, resovit and limestone. Furthermore, adhesive materials (binder) and water-repellent oils are added, in order to increase the mechanical strength of the materials, though the use of these elements must be kept within limits to achieve a high fire resistance. Stone wool consists of the same basic materials as glass wool. Its main differences concern the higher melting temperatures during the production process and the different size of the fibres. These differences make stone wool heavier, with a higher melting point and hence better suited for high temperature applications [1]. Results of fire tests confirm the better performance of stone wool than glass wool

\footnotetext{
* Correspondence should be addressed to: Andrea Frangi, E-mail: frangi@ibk.baug.ethz.ch
} 
when directly exposed to fire, but it is also known that glass wool and stone wool perform equally when protected from direct flames, e.g. by gypsum plasterboards $[2,3]$.

A new light mineral wool was developed by ISOVER based on the glass wool technology. The new light mineral wool offers the same properties as traditional glass wool in terms of insulation and easy handling. The major new feature lies in its improved resistance to high temperatures. A comprehensive research project on the fire performance of the new mineral wool has been carried out at ETH Zurich in collaboration with the Swiss Federal Laboratories for Materials Science and Technology (EMPA). A large number of small-scale fire tests permitted the analysis of different parameters (material, density, thickness) on the fire performance of the new mineral wool [4]. The results of the fire tests allowed the verification and calibration of thermal properties used for thermal finite element (FE) analysis. Based on an extensive FE parametric study, the coefficients for the new mineral wool to be used in the design model for the verification of the separating function of light timber frame wall and floor assemblies were calculated.

The paper first describes the main results of the experimental and numerical analyses. Then, the calculation of the coefficients for the new mineral wool to be used in the design model for the verification of the separating function of light timber frame wall and floor assemblies are presented.

\section{Design Model for the Verification of the Separating Function}

In order to limit fire spread by providing adequate fire compartmentation, elements forming the boundaries of fire compartments are designed and constructed in such a way that they maintain their separating function during the required fire exposure (insulation and integrity criteria). While fire tests are still widely used for the verification of the separating function, design models are becoming increasingly common. In timber buildings, walls and floors are mostly built up by adding different layers to form an assembly. For the verification of the separating function of timber assemblies, component additive methods are used [5]. These models are called component additive models, since the fire resistance of a layered construction is obtained by adding the contribution to the fire resistance of the different layers. The current design method according to Eurocode 5 (EN 1995-1-2) Annex E [6] is based on input data that was deduced from a limited number of fire tests on wall assemblies and therefore only covers a limited range of timber structures [7]. For this reason a research project on the separating function of timber assemblies was conducted and recently completed at ETH Zurich $[8,9]$. As a final result, an improved design method for the verification of separating function of timber constructions has been developed based on an extensive experimental as well as finite element thermal analysis. The design method is capable of considering timber assemblies with an unlimited number of layers made of gypsum plasterboards, wood panels or combinations thereof. The cavity may be void or filled with insulation made of stone or glass wool. 


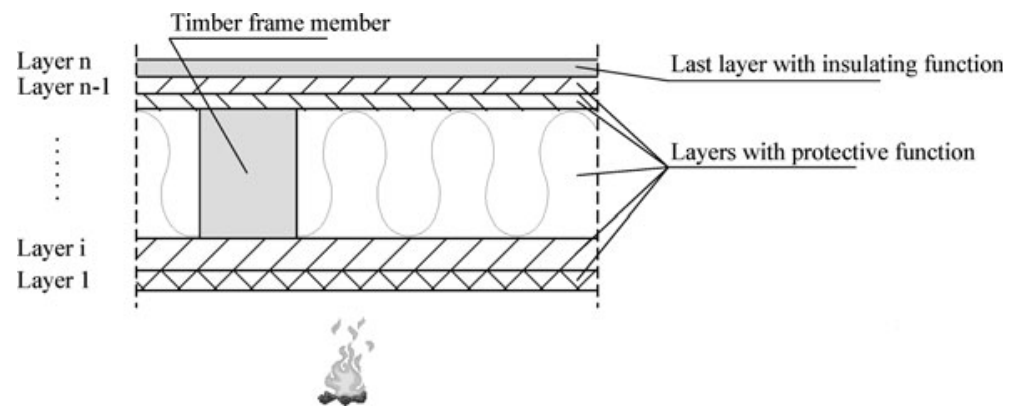

\section{Figure 1. Timber frame wall and floor assemblies: numbering and function of the different layers.}

In the following, the basic principle of the improved design method for the verification of the separating function of timber constructions is explained. All details of the design method can be found in $[8,9]$. The total fire resistance time is taken according to Equation 1 as the sum of the contributions from the different layers (claddings, void or insulated cavities), according to their function and interaction (see Figure 1):

$$
\mathrm{t}_{\text {ins }}=\sum_{\mathrm{i}=1}^{\mathrm{i}=\mathrm{n}-1} \mathrm{t}_{\text {prot }, \mathrm{i}}+\mathrm{t}_{\mathrm{ins}, \mathrm{n}}
$$

with $\sum_{\mathrm{i}=1}^{\mathrm{i}=\mathrm{n}-1} \mathrm{t}_{\text {prot, }, \mathrm{i}}$, sum of the protection times $\mathrm{t}_{\text {prot, } \mathrm{i}}$ of the layers (in the direction of the heat flux) preceding the last layer of the assembly on the fire-unexposed side (min) and $t_{i n s, n}$, insulation time $t_{i n s, n}$ of the last layer of the assembly on the fire-unexposed side (min).

Protection and insulation values of the layers can be calculated according to Equations 2 and 3 taking into account the basic values of the layers, the coefficients for the position of the layers in the assembly and the coefficients for the joint configurations:

$$
\begin{aligned}
& \mathrm{t}_{\text {prot,i }}=\left(\mathrm{t}_{\text {prot }, 0, \mathrm{i}} \cdot \mathrm{k}_{\text {pos,exp,i }} \cdot \mathrm{k}_{\text {pos,unexp,i }}+\Delta \mathrm{t}_{\mathrm{i}}\right) \cdot \mathrm{k}_{\mathrm{j}, \mathrm{i}} \\
& \mathrm{t}_{\text {ins, } \mathrm{n}}=\left(\mathrm{t}_{\text {ins }, 0, \mathrm{n}} \cdot \mathrm{k}_{\text {pos,exp }, \mathrm{n}}+\Delta \mathrm{t}_{\mathrm{n}}\right) \cdot \mathrm{k}_{\mathrm{j}, \mathrm{n}}
\end{aligned}
$$

with $t_{\text {prot, } 0, i}$, basic protection value (min) of layer $i$; $t_{i n s, 0, n}$, basic insulation value (min) of the last layer $\mathrm{n}$ of the assembly on the fire-unexposed side; $\mathrm{k}_{\mathrm{pos}, \exp , \mathrm{i}}$, $\mathrm{k}_{\text {pos,exp, } \mathrm{n}}$, position coefficient that takes into account the influence of layers preceding the layer considered; $\mathrm{k}_{\text {pos,unexp, }}$, position coefficient that takes into account the influence of layers backing the layer considered; $\Delta \mathrm{t}_{\mathrm{i}}, \Delta \mathrm{t}_{\mathrm{n}}$, correction time (min) for layers protected by Type $\mathrm{F}$ gypsum plasterboards as well as gypsum fibreboards; and $\mathrm{k}_{\mathrm{j}, \mathrm{i}}, \mathrm{k}_{\mathrm{j}, \mathrm{n}}$, joint coefficient. 
The coefficients of the design method (basic times $t_{\text {prot, } 0}$ and $t_{\text {ins, } 0}$, correction time $\Delta \mathrm{t}_{\mathrm{i}}$ as well as position coefficients $\mathrm{k}_{\text {pos,exp }}$ und $\mathrm{k}_{\text {pos,unexp }}$ ) were calculated for different materials by extensive FE thermal simulations based on physical models for the heat transfer through separating multiple layered construction $[8,9]$. The material properties used for the FE thermal simulations were calibrated by fire tests performed on unloaded specimens at the EMPA using ISO-fire exposure and validated by additional fire tests [8]. The same procedure is used for the evaluation and calculation of the coefficients of the design method for the new mineral wool.

The basic insulation value $t_{\text {ins, } 0}$ corresponds to the fire resistance of a single layer without the influence of adjacent materials and joints, i.e. the average temperature rise over the whole of the unexposed surface is limited to $140 \mathrm{~K}$, and the maximum temperature rise at any point of that surface does not exceed $180 \mathrm{~K}$. The basic insulation value can be assessed by tests or FE thermal analysis. For FE thermal analysis only the temperature rise criterion of $140 \mathrm{~K}$ is used. Further, the temperature of the layer at the beginning of the analysis on the fire-exposed side as well as on the fire-unexposed side is assumed as $20^{\circ} \mathrm{C}$. The definition of the basic insulation value $t_{\text {ins }, 0}$ is illustrated in Figure 2.

Wall and floor assemblies consisting of a single layer are only of limited application in timber assemblies. Most constructions consist of assemblies having two or more layers. The contribution to the separating function of the construction of each layer (except the last layer of the assembly on the fire-unexposed side) is mainly the protection of the following layers (see Figure 1). Therefore it seems more appropriate to introduce a basic protection value $t_{\text {prot, } 0}$ defined as the time until failure of the protective function. In analogy to the calculation for fire protective claddings of load-bearing timber constructions according to EN 13501-2 [10] the definition of the basic protection value $t_{\text {prot }, 0}$ is illustrated in Figure 3 . The testing method for fire protective cladding is performed with a particleboard of thickness $19 \mathrm{~mm}$ backing the layer under consideration. The contribution to the fire protection of this cladding may be assumed to be satisfied where the average temperature rise over the whole exposed surface of the particleboard is limited to $250 \mathrm{~K}$, and the maximum temperature rise at any point of that surface does not exceed $270 \mathrm{~K}$. For FE thermal analysis, only the average temperature rise criterion of $250 \mathrm{~K}$ is used. Further, the temperature of the layer at the beginning of
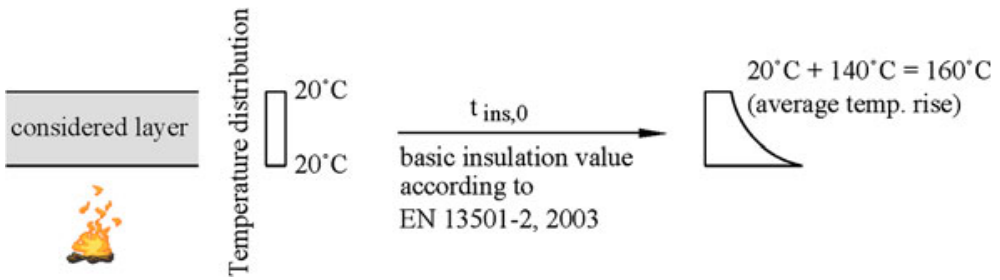

Figure 2. Definition of the basic insulation value $t_{i n s, 0}$ according to EN 13501-2 [10] (the average temperature rise over the whole of the unexposed surface is limited to $140 \mathrm{~K})$. 


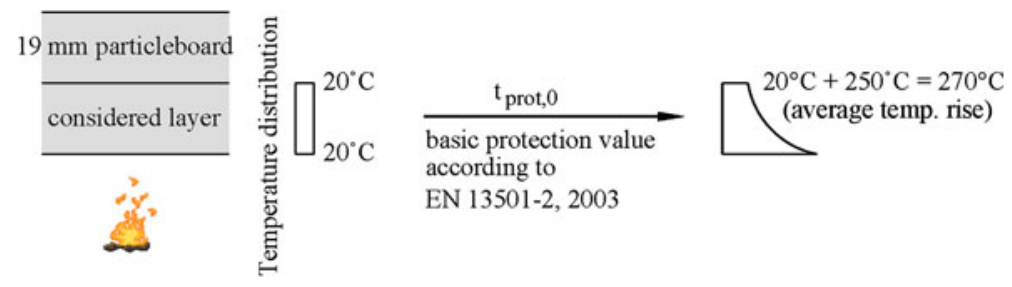

\section{Figure 3. Definition of the basic protection value $t_{\text {prot, }}, 0$ according to EN 13501-2 [10] (the average temperature rise over the whole of the exposed surface of the particleboard is limited to $250 \mathrm{~K}$ ).}

the analysis on the fire-exposed side as well as on the unexposed side is assumed to be $20^{\circ} \mathrm{C}$.

The joint coefficient $\mathrm{k}_{\mathrm{j}}$ considers the joint details and their influence on the protection and insulation values of layers with joints. The position coefficient considers the position of the layer within the assembly (in direction of the heat flux), because the layers preceding and backing the layer have an influence on its fire behaviour. The position coefficient $\mathrm{k}_{\text {pos,exp }}$ takes into account the influence of the layers preceding the layer under consideration, while the influence of the layer backing this layer is considered by $k_{\text {pos,unexp }}$. The position coefficients $k_{\text {pos,exp }}$ were calculated by extensive FE thermal simulations assuming that the layers fall off when the temperature of $270^{\circ} \mathrm{C}$ is reached on the fire-unexposed side of the layers. Fire tests showed that this assumption is conservative for gypsum plasterboards of type F according to EN 520 [11] or gypsum fibreboards according to EN 15283-2 [12]. Therefore the protection or insulation values of layers protected by gypsum plasterboards type $\mathrm{F}$ or gypsum fibreboards can be increased by using a correction time $\Delta \mathrm{t}_{\mathrm{i}}$.

In the following, the main results of experimental and numerical analyses, the calculation of the basic protection value $t_{\text {prot, }, 0}$, the position coefficients $k_{\text {pos,exp }}$ and $\mathrm{k}_{\mathrm{pos} \text {,unexp }}$ for the new mineral wool are described. The joint coefficients are not the subject of this paper.

\section{Fire Tests}

A series of 12 small-scale fire tests (in the following mentioned as V) was performed with unloaded specimens using mineral wool directly exposed to ISO-fire [13]. The fire tests were carried out in the EMPA's horizontal small furnace with the internal dimensions of $1.0 \times 0.8 \mathrm{~m}$ (see Figure 4). The objective of the fire tests was to provide fundamental experimental data on the fire behaviour of the new mineral wool. Thus, small-scale fire tests with unloaded specimens were performed. The mechanical behaviour of the mineral wool (e.g. falling off) was not the subject of the fire tests carried out.

The test specimens consisted of boxes made of particleboards filled with mineral wool (see Figure 4). In addition to the new fire resistant mineral wool, common stone wool as well as glass wool was tested. As test parameters, the density 

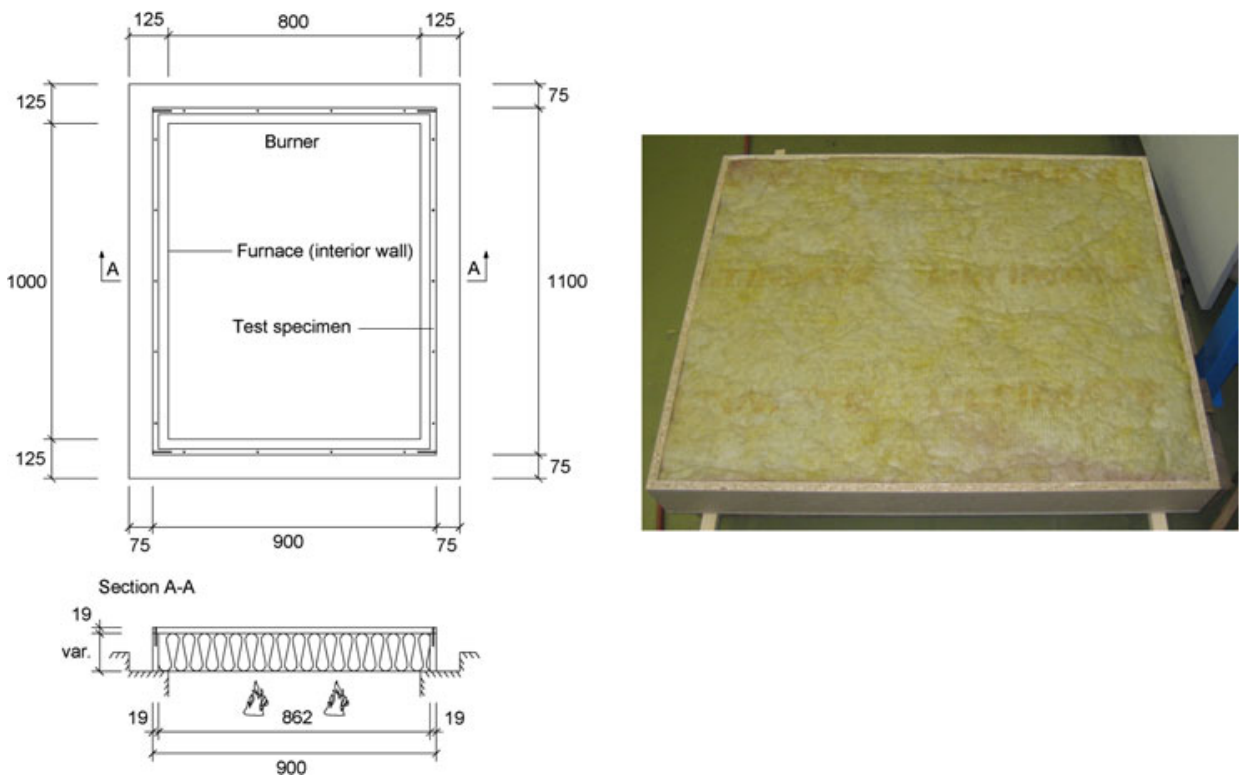

Figure 4. Test specimens for the small-scale fire tests using mineral wool.

\section{Table 1 \\ Thickness and Mean Density of the Mineral Wool Tested Under ISO-Fire Exposure}

\begin{tabular}{llcc}
\hline Test & \multicolumn{1}{c}{ Type } & Thickness, $\mathrm{mm}$ & Density, $\mathrm{kg} / \mathrm{m}^{3}$ \\
\hline V1-16 & New fire resistant mineral wool & 40 & 15.7 \\
V2-16 & New fire resistant mineral wool & 80 & 17.0 \\
V3-16 & New fire resistant mineral wool & 120 & 16.3 \\
V1-20 & New fire resistant mineral wool & 40 & 21.7 \\
V2-20 & New fire resistant mineral wool & 80 & 19.9 \\
V3-20 & New fire resistant mineral wool & 120 & 19.6 \\
V3u-20 & New fire resistant mineral wool & 120 & 20.4 \\
V1-25 & New fire resistant mineral wool & 40 & 28.3 \\
V2-25 & New fire resistant mineral wool & 80 & 27.3 \\
V3-25 & New fire resistant mineral wool & 120 & 26.4 \\
VS-30 & Stone wool & 120 & 28.3 \\
VG-20 & Glass wool & 120 & 20.3 \\
\hline
\end{tabular}

$\left(16 \mathrm{~kg} / \mathrm{m}^{3}, 20 \mathrm{~kg} / \mathrm{m}^{3}\right.$ and $\left.25 \mathrm{~kg} / \mathrm{m}^{3}\right)$ as well as the thickness $(40 \mathrm{~mm}, 80 \mathrm{~mm}$ and $120 \mathrm{~mm}$ ) of the new mineral wool was varied. Table 1 gives the effective measured density as well as the thickness of the mineral wool tested. Particleboards according to EN 312 [14] with a mean density of $647 \mathrm{~kg} / \mathrm{m}^{3}$ were used for the fabrication of the boxes. 


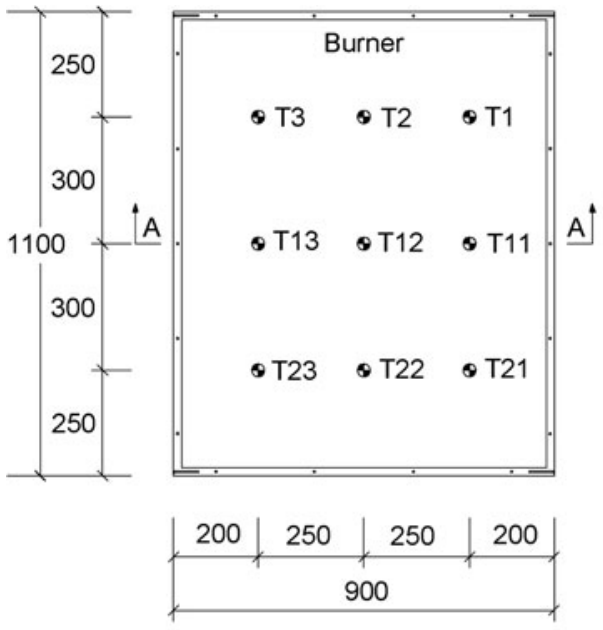

Section A-A

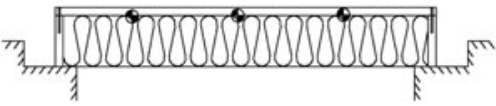

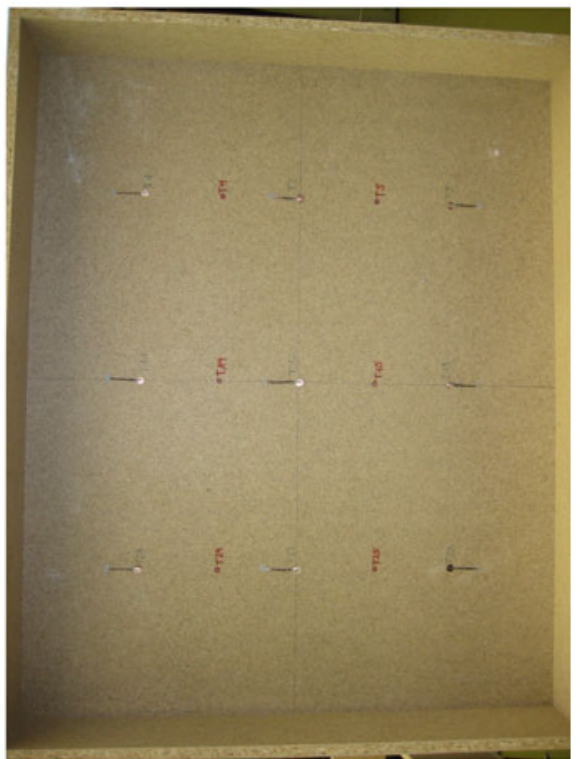

\section{Figure 5. Position of thermocouples placed between mineral wool and particleboard.}

During the tests, the temperature at the interface between mineral wool and particleboard was measured using nine thermocouples of type $\mathrm{K}$. The thermocouples were placed on the fire-exposed side of the particleboard (see Figure 5). The fire tests were stopped when a temperature of about $350^{\circ} \mathrm{C}$ was measured at the interface between mineral wool and particleboard. All details of the fire tests can be found in [4].

Figure 6 shows the temperature development at the interface between mineral wool and particleboard for all fire tests performed with the new fire resistant mineral wool. It can be seen that the temperature development depends on the thickness and density of the mineral wool. By increasing thickness as well as density of the mineral wool the temperature increase at the interface between mineral wool and particleboard is delayed.

Table 2 gives the measured basic protection value $t_{\text {prot, } 0}$ for all fire tests performed with the new fire resistant mineral wool based on the criteria of temperature rise of $250 \mathrm{~K}$ (temperature mean value) and $270 \mathrm{~K}$ (maximum temperature rise at any point of the surface of the particleboard). The shortest basic protection value $t_{\text {prot, } 0}$ was measured for the fire test V1-16 (with thickness of $40 \mathrm{~mm}$ and nominal density of $16 \mathrm{~kg} / \mathrm{m}^{2}$ ). By increasing thickness as well as density of the mineral wool, the basic protection value $t_{\text {prot }, 0}$ increased. The longest basic protection value $t_{\text {prot, } 0}$ was measured for the fire test V3-25 (with thickness of $120 \mathrm{~mm}$ and nominal density of $25 \mathrm{~kg} / \mathrm{m}^{2}$ ). Noticeable is that the differences between the measured basic protection value $t_{\text {prot, } 0}$ based on the two temperature criteria were quite small (less than $3 \mathrm{~min}$ ). 

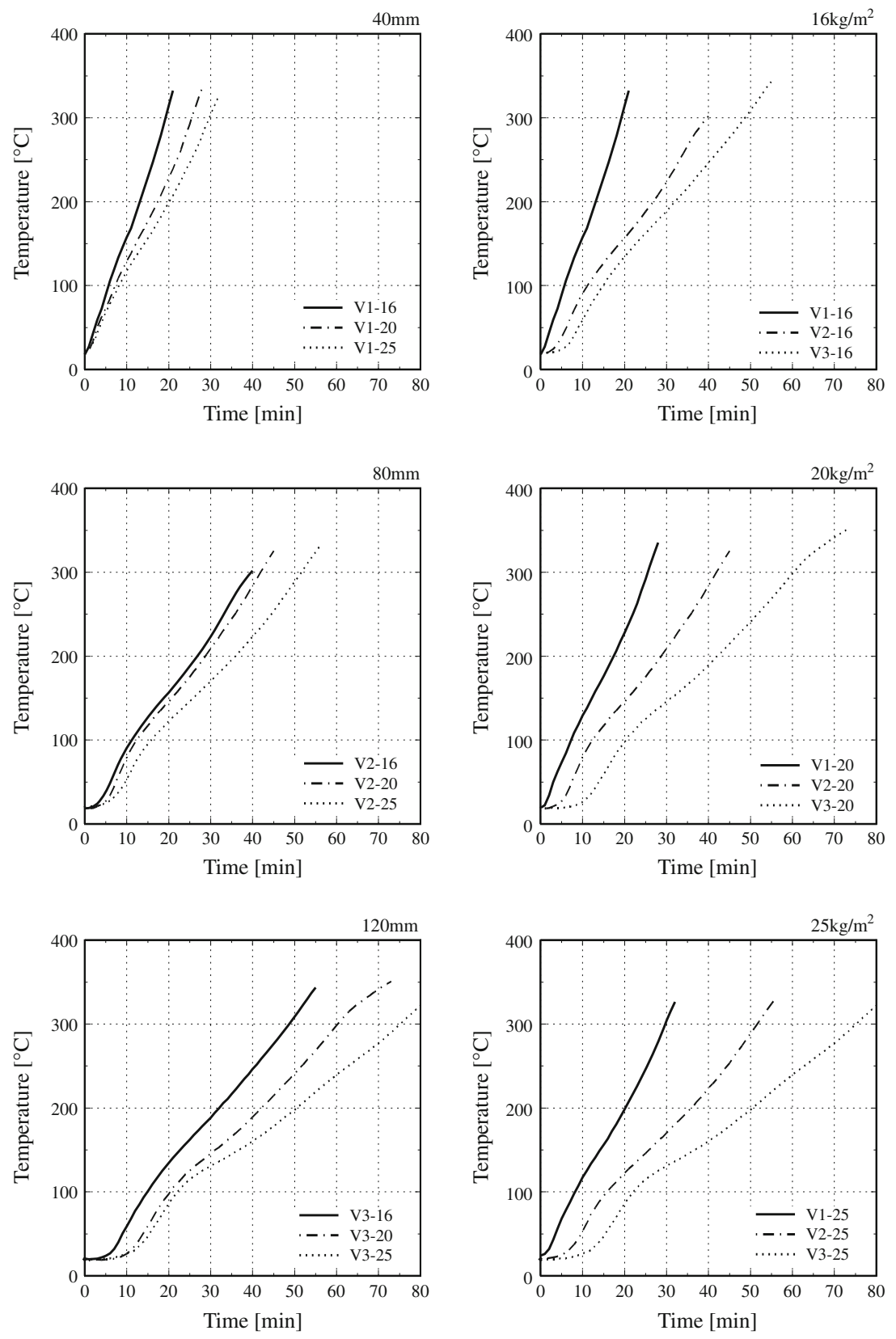

Figure 6. Temperature development at the interface between mineral wool and particleboard for all fire tests performed with the new mineral wool. 


\section{Table 2}

Measured Basic Protection Value tprot,o

\begin{tabular}{lcccc}
\hline Test & Thickness, mm & Density, $\mathrm{kg} / \mathrm{m}^{3}$ & $\begin{array}{c}\mathrm{t}_{\text {prot }, 0}, \mathrm{~min}, \\
\text { based on } \Delta 270 \mathrm{~K} \\
\text { (maximum temperature rise) }\end{array}$ & $\begin{array}{c}\mathrm{t}_{\text {prot, },}, \text { min, based on } \\
\Delta 250 \mathrm{~K} \text { (temperature } \\
\text { mean value) }\end{array}$ \\
\hline V1-16 & 40 & 15.7 & 15 & 18 \\
V2-16 & 80 & 17.0 & 29 & 32 \\
V3-16 & 120 & 16.3 & 43 & 44 \\
V1-20 & 40 & 21.7 & 22 & 23 \\
V2-20 & 80 & 19.9 & 37 & 38 \\
V3-20 & 120 & 19.6 & 50 & 53 \\
V3u-20 & 120 & 20.4 & 56 & 57 \\
V1-25 & 40 & 28.3 & 28 & 28 \\
V2-25 & 80 & 27.3 & 47 & 47 \\
V3-25 & 120 & 26.4 & 70 & 68 \\
\hline
\end{tabular}
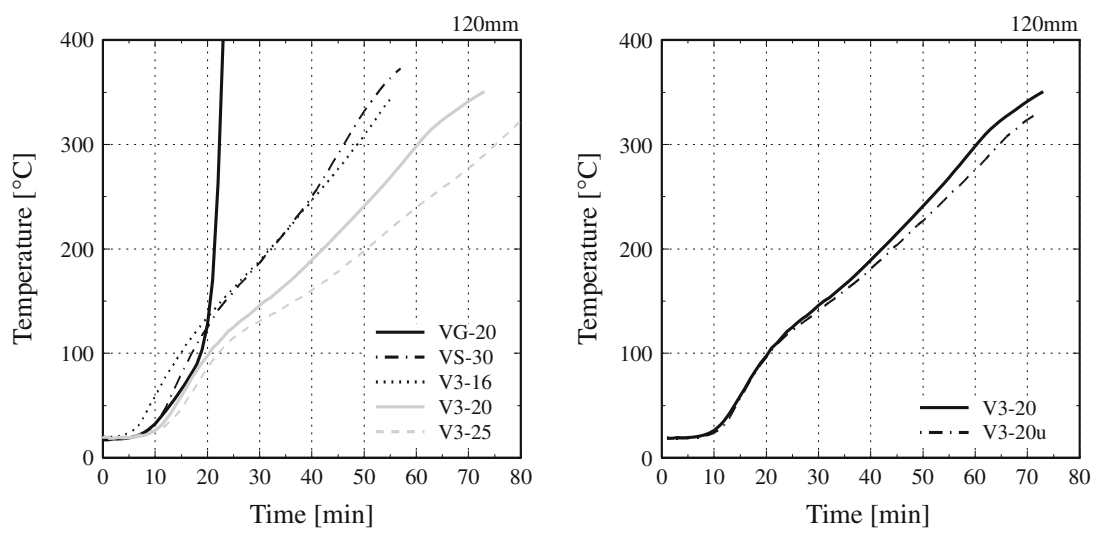

Figure 7. Temperature development at the interface between mineral wool and particleboard; left: comparison between different mineral wools (VG: glass wool; VS: stone wool; V3: new fire resistant mineral wool); right: influence of density variation over the crosssection of the mineral wool (V3-20: lighter side of the mineral wool directly exposed to fire; V3-20u: weightier side of the mineral wool directly exposed to fire).

Figure 7 left compares the fire performance of the new fire resistant mineral wool to common stone and glass wool. The thickness of the insulation was $120 \mathrm{~mm}$ for all tests considered. It can be seen that the fire performance of the new mineral wool with a density of about $16 \mathrm{~kg} / \mathrm{m}^{2}$ (test $\mathrm{V} 3-16$ ) was similar to that of the stone wool with a density of about $28 \mathrm{~kg} / \mathrm{m}^{3}$ (test VS-30). Noticeable is the strong temperature increase after about $18 \mathrm{~min}$ for the common glass wool. This effect is due to melting of the glass wool when exposed directly to fire. 


\section{Table 3}

Measured density variation over the cross-section of the new mineral wool with a thickness of $120 \mathrm{~mm}$ and a nominal density of $16 \mathrm{~kg} / \mathrm{m}^{3}$, $20 \mathrm{~kg} / \mathrm{m}^{3}$ and $25 \mathrm{~kg} / \mathrm{m}^{3}$, respectively

\begin{tabular}{lcccccr}
\hline & $\begin{array}{c}\text { Total } \\
\text { thickness, } \\
\mathrm{mm}\end{array}$ & $\begin{array}{c}\text { Nominal } \\
\text { density, } \\
\mathrm{kg} / \mathrm{m}^{3}\end{array}$ & $\begin{array}{c}\text { Density, } \\
\mathrm{kg} / \mathrm{m}^{3}, \\
\text { of part I, } \\
(40 \mathrm{~mm})\end{array}$ & $\begin{array}{c}\text { Density, } \\
\mathrm{kg} / \mathrm{m}^{3}, \\
\text { of part II } \\
(40 \mathrm{~mm})\end{array}$ & $\begin{array}{c}\text { Density, } \\
\mathrm{kg} / \mathrm{m}^{3}, \\
\text { of part III } \\
(40 \mathrm{~mm})\end{array}$ & $\begin{array}{c}\text { Mean } \\
\text { density, } \\
\mathrm{kg} / \mathrm{m}^{3}\end{array}$ \\
\hline New mineral wool & 120 & 16 & 13.0 & 15.6 & 15.6 & 15.7 \\
New mineral wool & 120 & 20 & 15.2 & 21.2 & 24.7 & 20.4 \\
New mineral wool & 120 & 25 & 24.0 & 26.6 & 26.0 & 26.5 \\
\hline
\end{tabular}

Because of production methodology, mineral wool usually shows a density variation over the cross-section. e.g. Table 3 showed the density measured in the new mineral wool batts with a thickness of $120 \mathrm{~mm}$ and a nominal density of $16 \mathrm{~kg} / \mathrm{m}^{3}, 20 \mathrm{~kg} / \mathrm{m}^{3}$ and $25 \mathrm{~kg} / \mathrm{m}^{3}$, respectively. The $120 \mathrm{~mm}$ thick mineral wool was cut in three parts with a thickness of $40 \mathrm{~mm}$ each and the density of each part was calculated based on the volume and weight measured. Figure 6 right compares the fire performance of the new mineral wool with the lighter side of the mineral wool directly exposed to fire (test V30-20) to the new mineral wool with the heavier side of the mineral wool directly exposed to fire (test V30-20u). It can be seen that for both tests the temperature development was identical up to a temperature of about $150^{\circ} \mathrm{C}$ and then for the specimen with the lighter side of the mineral wool directly exposed to fire the temperature increased slightly faster. However, the difference between the two tests is very small and is of no real significance under consideration that there may be large variation in the results if multiple tests were undertaken.

\section{FE Thermal Analysis}

For the calculation of the temperature development in the new mineral wool subjected to ISO-fire a FE thermal analysis was conducted using ANSYS [15]. The heat transfer to the surface of the mineral wool was calculated using temperature-independent constant values according to EN 1991-1-2 [16] for the resultant emissivity by radiation $\varepsilon_{\text {res }}=0.8$ and the coefficient of heat transfer by convection $\alpha_{\mathrm{c}, \text { exp }}=25 \mathrm{~W} / \mathrm{m}^{2} \mathrm{~K}$ and $\alpha_{\mathrm{c} \text {,unexp }}=4 \mathrm{~W} / \mathrm{m}^{2} \mathrm{~K}$. Density, thermal conductivity and specific heat capacity of the mineral wool vary as a function of temperature. Unfortunately, the thermal properties of materials at high temperatures are difficult to measure. Transient effects and the method of measurement can have a significant effect on the test results [17]. Thus, the thermal properties are usually calibrated with results of fire tests and the values used in FE thermal analyses are often "apparent" values rather than "real" physically-correct material properties [18]. 

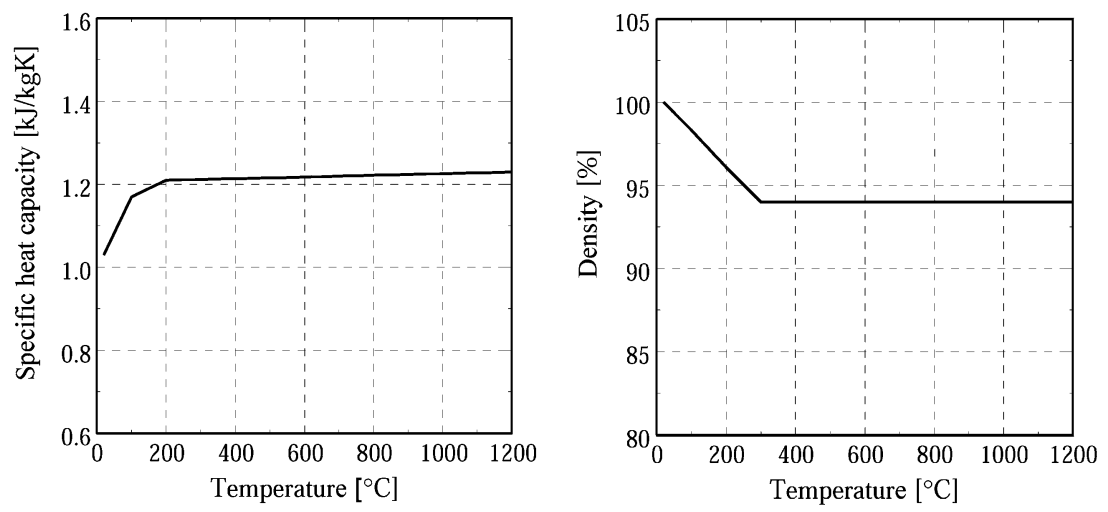

\section{Figure 8. Temperature-dependent specific heat capacity (left) and density (right) of the new mineral wool used for the FE thermal analysis in this study.}

For this study, for the new mineral wool, the same temperature-dependent variation of density and specific heat capacity, as for common glass wool, was assumed as given in [8] (see Figure 8). ISOVER experimentally determined the temperature-dependent thermal conductivity of the new mineral wool up to a temperature of $600^{\circ} \mathrm{C}$. The experimental results showed a non linear relationship for the temperature-dependent thermal conductivity of the mineral wool. Further, the thermal conductivity is a function of the density of the mineral wool. Based on the experimental results, Equation 4 was developed for the calculation of the temperature-dependent thermal conductivity of the new mineral wool:

$$
\lambda(\mathrm{T})=0.000025 \rho^{-1.152} \mathrm{~T}^{2}+0.0001 \mathrm{~T}+\left(0.000007 \rho^{2}-0.0006 \rho+0.044\right)
$$

with $\lambda(\mathrm{T})$, thermal conductivity $(\mathrm{W} / \mathrm{mK}) ; \mathrm{T}$, temperature $\left({ }^{\circ} \mathrm{C}\right)$; and $\rho$, density of the mineral wool $\left(\mathrm{kg} / \mathrm{m}^{3}\right)$.

Figure 9 compares the results of the FE thermal analysis with the results of the small-scale fire tests on the new mineral wool with a density of $20 \mathrm{~kg} / \mathrm{m}^{3}$ and a thickness of $40 \mathrm{~mm}, 80 \mathrm{~mm}$ and $120 \mathrm{~mm}$. It can be seen that the FE thermal analysis predicted the temperature development of the new mineral wool with a thickness of $40 \mathrm{~mm}$ satisfactorily. For the mineral wool with a thickness of $80 \mathrm{~mm}$ and $120 \mathrm{~mm}$ the temperature increase based on the FE thermal analysis was underestimated, i.e. it occurred slower than in comparison to the fire tests. This effect was observed also for the tests performed with mineral wool with the density of $16 \mathrm{~kg} / \mathrm{m}^{3}$ and $25 \mathrm{~kg} / \mathrm{m}^{3}$. A possible reason is that physical phenomena such as the combustion of the binder at high temperature are explicitly ignored in the calculation model. For this reason, the thermal conductivity was modified by a factor $\mathrm{k}$ as a function of the thickness of the mineral wool (see Equation 5). The correction factor $\mathrm{k}$ was calculated by calibration of the results of the FE thermal analysis with the results of the fire tests. 


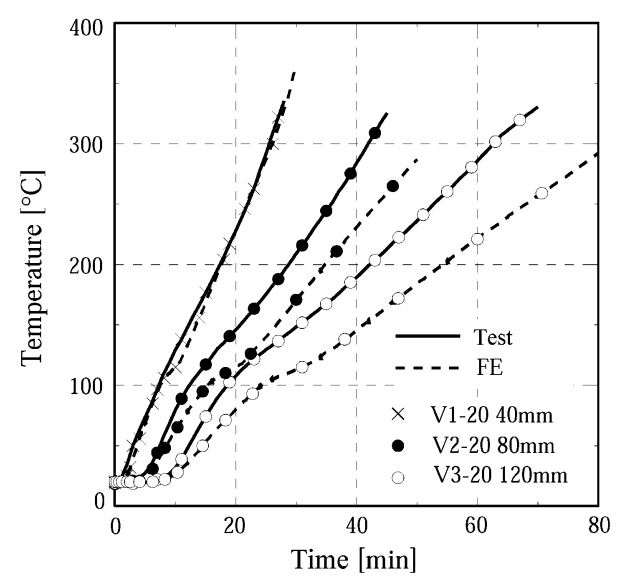

Figure 9. Comparison between fire tests and FE thermal analysis using the temperature-dependent thermal conductivity according to Equation 4 for the small-scale fire tests performed with the new mineral wool with the density of $20 \mathrm{~kg} / \mathrm{m}^{3}$.

$$
\mathrm{k}=0.0047 \mathrm{~h}+0.9
$$

with $\mathrm{k}$, factor [-] and $\mathrm{h}$, thickness of the mineral wool (mm).

Figure 10 compares the results of the FE thermal analysis using the modified thermal conductivity with the results of all small-scale fire tests. The FE thermal analysis predicted the overall temperature development for most of the fire tests satisfactorily. Only for the test V3-20 (density of $20 \mathrm{~kg} / \mathrm{m}^{3}$ and thickness of $120 \mathrm{~mm}$ ) the temperature increase based on the FE thermal analysis occurred faster than in comparison to the fire tests, i.e. the FE thermal analysis led to a conservative result. The difference between measured and calculated basic protection value $t_{\text {prot, } 0}$ was about $7 \mathrm{~min}$.

The results of the small-scale fire tests were used to calibrate the material properties assumed for the FE thermal analysis. In this way, the thermal behaviour of the mineral wool was not influenced by other layers. In [19] the results of a series of full-scale fire tests with non load-bearing light timber frame wall assemblies filled with the new mineral wool with a thickness of $145 \mathrm{~mm}$ is reported. Figure 11 left shows the comparison between FE thermal analysis and three fire tests with the new mineral wool that was exposed directly to ISO-fire. It can be seen that the temperature increase based on the FE thermal analysis occurred up to about $200^{\circ} \mathrm{C}$ slower than in comparison to the fire tests, i.e. the FE thermal analysis led to non conservative results. However, in the temperature ranges between $200^{\circ} \mathrm{C}$ and $300^{\circ} \mathrm{C}$ the $\mathrm{FE}$ thermal analysis well predicted the temperature development. Figure 11 right shows the comparison between FE thermal analysis and a fire test with the new mineral wool that was protected by a $12.5 \mathrm{~mm}$ thick gypsum plasterboard type A according to EN 520. Density, thermal conductivity and specific heat capacity for the gypsum plasterboard type A vary as a function of 

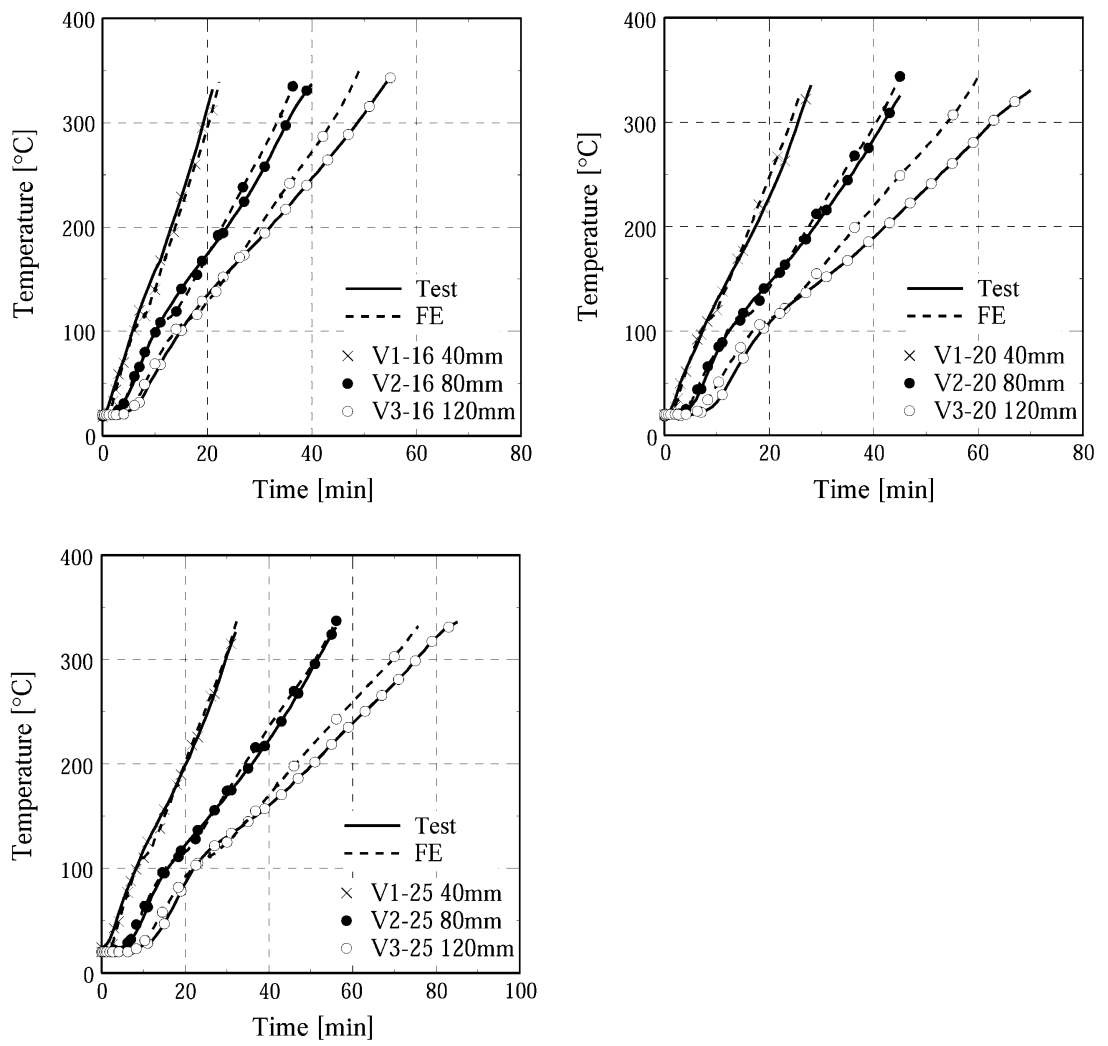

Figure 10. Comparison between fire tests and FE thermal analysis using the modified temperafure-dependent thermal conductivity according to Equations 4 and 5 for all small-scale fire tests performed with the new mineral wool.

temperature and are based on [8]. It can be seen that the FE thermal analysis predicted the temperature development on the fire unexposed side of the gypsum plasterboard as well as the mineral wool satisfactorily.

\section{Coefficients of the Design Method}

Based on the FE thermal analysis, Equation 6 was developed for the calculation of the basic protection value $t_{\text {prot, } 0}$ of the new fire resistant mineral wool (see Figure 12). The basic protection value was calculated in analogy to the testing method for fire protective claddings given in EN 13501-2, i.e. considering the new mineral wool backed by a $19 \mathrm{~mm}$ thick particleboard (see Figure 3). The temperature of the layers at the beginning of the analysis on the fire-exposed side as well as on the unexposed side was assumed to be $20^{\circ} \mathrm{C}$. For FE thermal analysis, only the average temperature rise criterion of $250 \mathrm{~K}$ was used. 

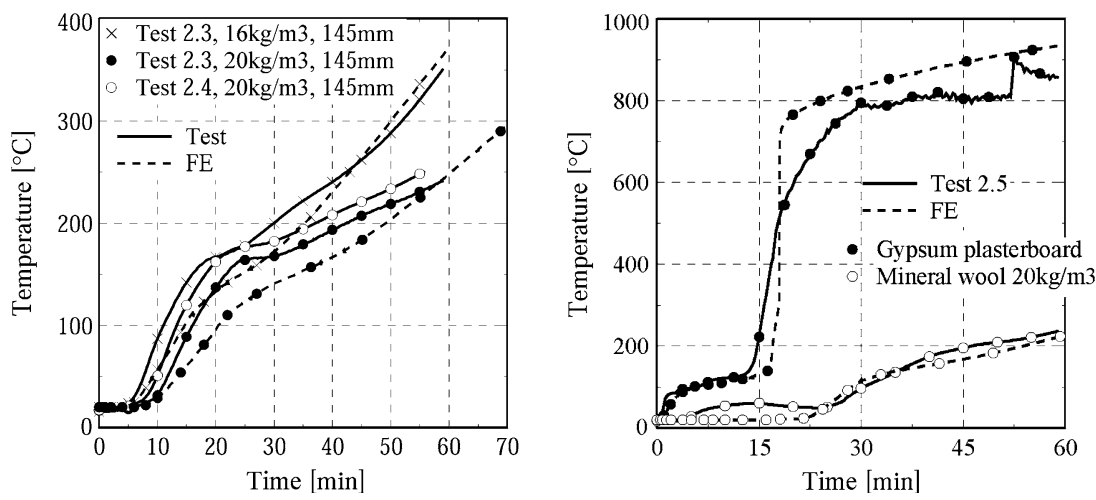

Figure 11. Comparison bełween measured and calculated temperatures for four full-scale fire tests reported in [2 1 ] with non load-bearing light timber frame wall assemblies filled with the new mineral wool with $145 \mathrm{~mm}$ thickness.

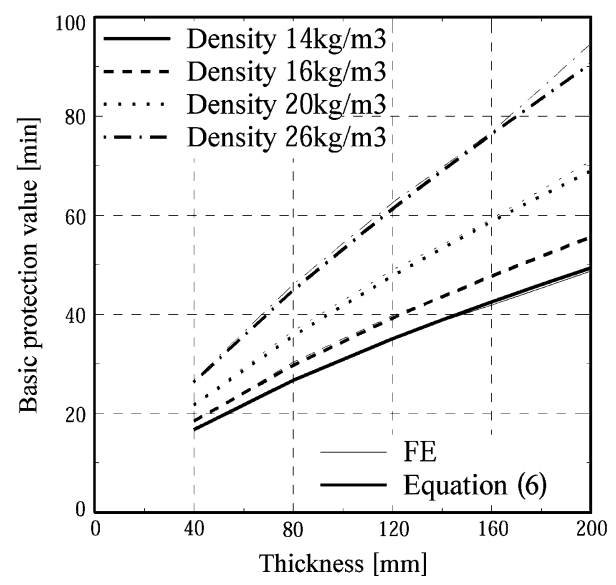

Figure 12. Basic protection value $t_{\text {prot, }}, 0$ of the new mineral wool calculated based on FE-thermal analysis and Equation 6.

$$
\mathrm{t}_{\text {prot }, 0}=\left(-0.0012 \rho^{2}+0.06 \rho+0.8\right) \mathrm{h}^{0.008 \rho+0.56} \text { for } 40 \mathrm{~mm} \leq \mathrm{h} \leq 145 \mathrm{~mm}
$$

with $\rho$, density of the new mineral wool $\left(\mathrm{kg} / \mathrm{m}^{3}\right)$ and $\mathrm{h}$, thickness of the new mineral wool (mm).

Figure 13 shows the basic protection value $t_{\text {prot }, 0}$ of the new mineral wool calculated based on Equation 6 in comparison to $t_{\text {prot }, 0}$ measured in all small-scale fire tests as well as in other fire tests found in the literature [19, 20]. All fire tests considered in Figure 13 were performed with the new mineral wool directly exposed 


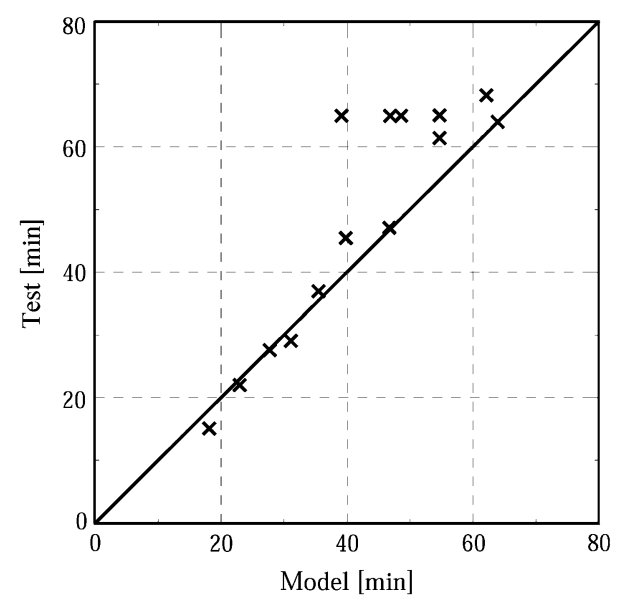

Figure 13. Comparison bełween measured and calculated basic protection value $t_{\text {prot, }}, 0$ of the new mineral wool directly exposed to fire considering all small-scale fire tests [4] as well as other fire tests found in the literature $[19,20]$.

to fire and backed by timber board. It can be seen that for the majority of the fire tests Equation 6 well predicted the basic protection value. For few fire tests the basic protection value calculated based on Equation 6 was underestimated, i.e. the calculation model led to safe results.

In [8] the influence of the layers preceding and backing the layer considered was analysed separately. The position coefficient $\mathrm{k}_{\text {pos,exp }}$ considers the influence of the layers preceding the layer studied, while the influence of the layer backing the layer studied is considered by $\mathrm{k}_{\text {pos,unexp. }}$ The position coefficients for different materials were systematically calculated using FE thermal analysis. The results of the FE thermal analysis showed that the position coefficient $\mathrm{k}_{\text {pos,exp }}$ is mainly influenced by the furnace temperature at the time when the layer considered is exposed directly to fire as well as the material and thickness of the layer considered, while the influence of preheating is small [21]. As the design model for the verification of the separating function of timber assemblies is developed for ISOfire exposure, the furnace temperature is a function of the sum of the protection values of the preceding layers (i.e. $\left.\sum \mathrm{t}_{\text {prot,i-1 }}\right)$. The thickness of the layer considered is expressed by its basic protection value $t_{p r o t, 0, i}$ or basic insulation value $\mathrm{t}_{\mathrm{ins}, 0, \mathrm{n}}$. Thus, it was possible to determine the position coefficient $\mathrm{k}_{\mathrm{pos}, \exp }$ as a function of the sum of the protection values of the layers preceding the layer considered $\left(\sum t_{\text {prot, }, i-1}\right)$ and the basic values of the layer considered ( $t_{\text {prot, }, 0, i}$ and $\left.t_{\mathrm{ins}, 0, \mathrm{n}}\right)$, making the calculation of $\mathrm{k}_{\text {posexp }}$ easy for the designer.

For stone wool the position coefficient $\mathrm{k}_{\mathrm{pos} \text { exp }}$ can be calculated as follows $[8,9]$ : 


$$
\mathrm{k}_{\text {pos }, \exp , \mathrm{i}}= \begin{cases}1-0.6 \frac{\sum \mathrm{t}_{\text {prot }, \mathrm{i}-1}}{\mathrm{t}_{\text {prot }, 0, \mathrm{i}}} & \text { for } \quad \sum \mathrm{t}_{\text {prot }, \mathrm{i}-1}<\frac{\mathrm{t}_{\text {prot } 0, \mathrm{i}}}{2} \\ 0.5 \sqrt{\frac{\mathrm{t}_{\text {prot }, 0, \mathrm{i}}}{\sum \mathrm{t}_{\text {prot }, \mathrm{i}-1}}} & \text { for } \quad \sum \mathrm{t}_{\text {prot }, \mathrm{i}-1} \geq \frac{\mathrm{t}_{\text {prot }, 0, \mathrm{i}}}{2}\end{cases}
$$

with $\mathrm{k}_{\text {pos,exp,i, }}$, position coefficient of layer $\mathrm{i}$ that takes into account the influence of layers preceding the layer considered; $\sum \mathrm{t}_{\text {prot, } \mathrm{i}-1}$, sum of the protection values of the preceding layers (min); and $t_{\text {prot }, 0, \mathrm{i}}$, basic protection values of layer $\mathrm{i}(\mathrm{min})$.

Figure 14 shows the calculated protection value for the new mineral wool with density of $20 \mathrm{~kg} / \mathrm{m}^{3}$ as a function of the sum of the protection values of the layers preceding the new mineral wool $\left(\sum \mathrm{t}_{\mathrm{prot}, \mathrm{i}-1}\right)$ based on FE thermal analysis as well as Equations 6 and 7. It can be seen that the position coefficient $k_{\text {pos,exp }}$ for the new fire resistant mineral wool can be calculated using Equation 7. Similar results were obtained also using the new mineral wool with densities of $16 \mathrm{~kg} / \mathrm{m}^{3}$ and $25 \mathrm{~kg} / \mathrm{m}^{3}$.

The influence of the layer backing the layer studied is considered by the position coefficient $k_{\text {pos,unexp. }}$. Results of fire tests supported by FE thermal analysis showed that the influence of the layer backing the layer considered is small if the backing layer is made of gypsum or timber, while insulating batts backing the layer considered caused the layer to heat up more rapidly, reducing the protection time of the layer $[8,9]$. Additional results of FE thermal analysis showed that the influence of the new mineral wool as backing layer is similar to the influence of

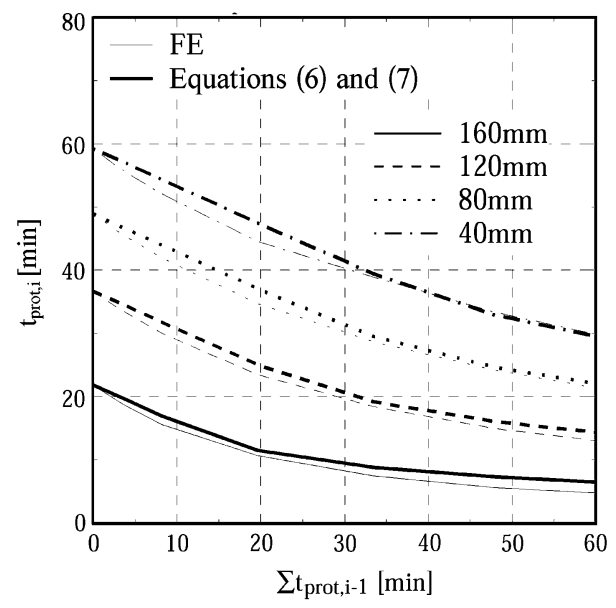

Figure 14. Protection value for the new mineral wool with density of $20 \mathrm{~kg} / \mathrm{m}^{3}$ and different thickness as a function of the sum of the protection values of the layers preceding the new mineral wool $\left(\sum t_{\text {prot,i-1 }}\right)$ calculated based on FE thermal analysis as well as Equations 6 and 7. 

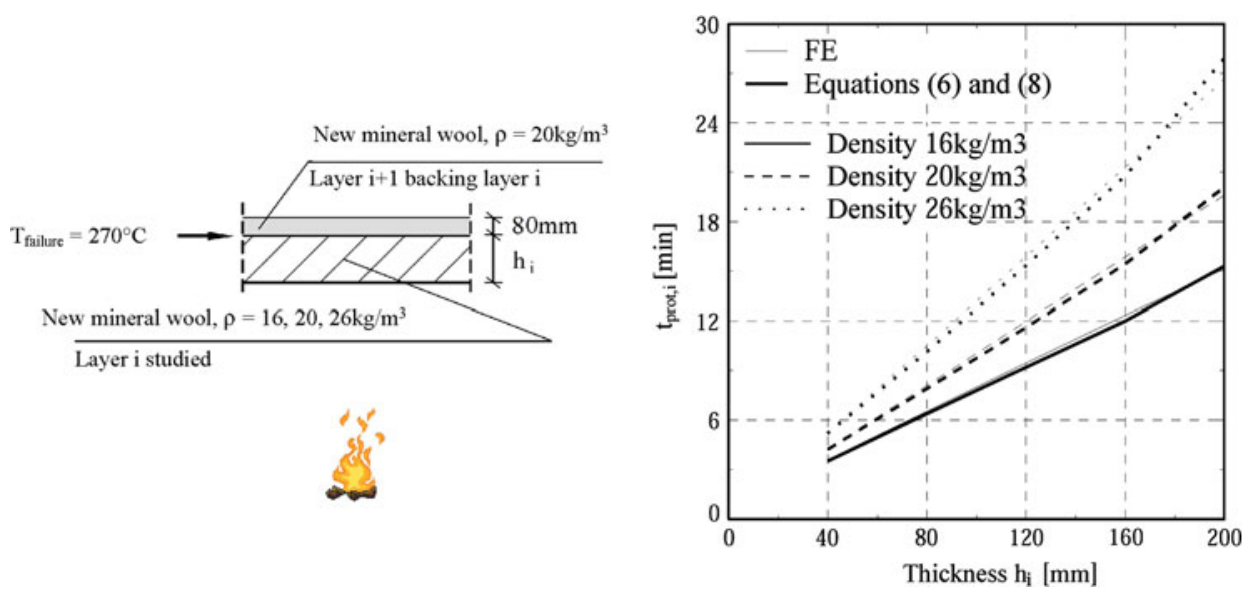

Figure 15. Left calculation model for the FE thermal analysis on the influence of an insulation backing the new mineral wool, right: Protection value for the new mineral wool with different densities as a function of the thickness of the new mineral wool based on FE thermal analysis as well as Equations 6 and 8.

stone and glass wool, i.e. the same position coefficient $\mathrm{k}_{\mathrm{pos} \text {,unexp }}$ as given in $[8,9]$ can be used.

The influence of an insulation backing the new mineral wool was studied according to Figure 15 left. As results of FE thermal analysis showed that the type, thickness and density of the insulation used as backing layers do not have an influence on the determination of $\mathrm{k}_{\text {pos,unexp }}$, the new mineral wool with thickness of $80 \mathrm{~mm}$ and a density of $20 \mathrm{~kg} / \mathrm{m}^{3}$ was used as backing material. Based on the results of FE thermal analysis the Equation 8 for the calculation of $k_{\text {pos,unexp }}$ for the new mineral wool backed by insulation was developed:

$$
\mathrm{k}_{\text {pos,unexp }}=0.00017 \rho^{0.4} \mathrm{~h}+0.17
$$

with $\mathrm{k}_{\text {pos,exp }}$, position coefficient for the new mineral wool backed by insulation; $\rho$, density of the new mineral wool $\left(\mathrm{kg} / \mathrm{m}^{3}\right)$; and $\mathrm{h}$, thickness of the new mineral wool (mm).

Figure 15 right shows the calculated protection value for the new mineral wool with different densities as a function of the thickness based on FE thermal analysis as well as Equations 6 and 8. It can be seen that the results of FE thermal analysis agree well with the results based on Equations 6 and 8 .

\section{Comparison to Fire Tests}

The design model for the verification of the separating function of light timber frame wall and floor assemblies given in $[8,9]$ was used for the calculation of the fire resistance of light timber frame wall and floor assemblies filled with the new 


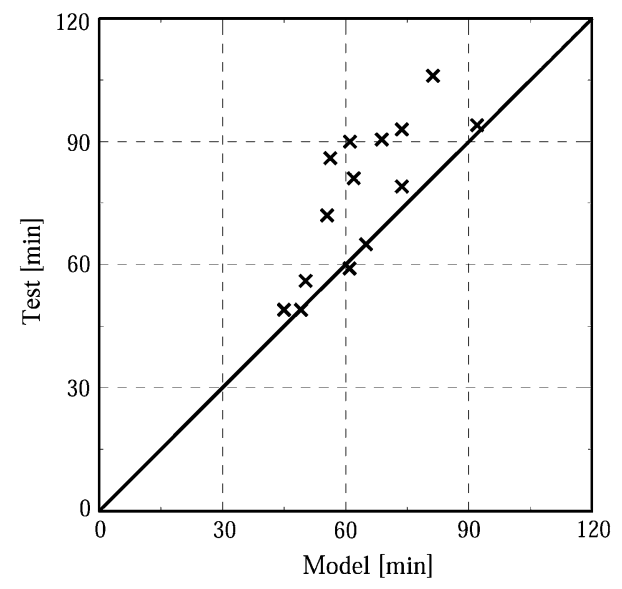

Figure 16. Comparison bełween the fire resistance measured and calculated according to the design method given in $[8,9]$ for fire tests on light timber frame wall and floor assemblies filled with the new mineral wool $[4,19,22]$.

mineral wool found in the literature $[4,19,22]$. The fire resistance was calculated using the coefficients developed for the new mineral wool and based on the temperature rise criterion of $140 \mathrm{~K}$ at the fire unexposed side of the assembly.

Figure 16 shows the comparison between the fire resistance measured and calculated according to the design method. It can be seen that the design method leads mostly to safe results. The analysis of the protocols of the fire tests showed that the observed differences between calculation model and fire tests are due to the falling-off of the claddings that often occurred later in comparison to the assumptions of the calculation model. However, conservative assumptions with regard to falling-off are necessary in order to cover the large variety of detailing of light frame wall and floor assemblies and the resulting large variability of falling-off times of claddings [23].

\section{Conclusions}

A large number of small-scale fire tests in combination with an extensive thermal finite element (FE) parametric study permitted the analysis of the fire performance of the new light mineral wool. From the analysis of the test results and FE thermal simulations the following conclusions can be drawn:

- the new light mineral wool showed improved resistance to high temperatures. By increasing thickness as well as density of the mineral wool the fire resistance was increased.

- the fire performance of the new light mineral wool with a density of about $16 \mathrm{~kg} / \mathrm{m}^{2}$ was comparable to that of common stone wool with a density of about $28 \mathrm{~kg} / \mathrm{m}^{3}$. 
- the fire performance of the new light mineral wool used in light timber frame wall and floor assemblies can be calculated with a design model recently developed for the verification of the separating function of timber constructions. The coefficients to be used in the design model were calculated based on an extensive FE parametric study.

\section{References}

1. Papadopoulos AM (2005) State of the art in thermal insulation materials and aims for future developments. Energy Build 37:77-86

2. Frangi A, Knobloch M, Fontana M (2009) Fire design of timber slabs made of hollow core elements. Eng Struct 31:150-157

3. Schleifer V, Frangi A, Fontana M (2007) Experimentelle Untersuchungen zum Brandverhalten von Plattenelementen, Institute of Structural Engineering IBK, ETH Zurich, IBK-report No. 302

4. Coray S, Hug R (2008) Brandverhalten von Dämmplatten aus Glaswolle, Projektarbeit (Master). Institute of Structural Engineering IBK, ETH Zurich

5. König J, Oksanen T, Towler K (2000) A review of component additive methods used for the determination of fire resistance of separating light timber frame construction, Paper CIB-W18/33-16-2, CIB Working Commission W18-Timber Structures, Delft, Netherlands

6. EN 1995-1-2 (2004) Eurocode 5-design of timber structures, part 1-2: general-structural fire design, European Standard, CEN, Brussels

7. König J (2005) Structural fire design according to Eurocode 5-design rules and their background. Fire Mater 29:147-163

8. Schleifer V (2009) Zum Verhalten von raumabschliessenden mehrschichtigen Holzbauteilen im Brandfall, PhD Thesis ETH No. 18156, ETH Zurich

9. Frangi A, Schleifer V, Fontana M (2010) Design model for the verification of the separating function of light timber frame assemblies. Eng Struct 32:1184-1195

10. EN 13501-2 (2007) Fire classification of construction products and building elements - part 2: classification using data from fire resistance tests, excluding ventilation services, European Standard, European Standard, CEN, Brussels

11. EN 520 (2004) Gypsum plasterboards, definitions, requirements and test methods, European Standard, CEN, Brussels

12. EN 15283-2 (2008) Gypsum boards with fibrous reinforcement-definitions, requirements and test methods-part 2: gypsum fibre boards; European Standard, CEN, Brussels

13. ISO 834-1 (1999) Fire-resistance tests - elements of building construction-part 1: general requirements

14. EN 312 (2003) Particleboards - specifications, European Standard, CEN, Brussels

15. ANSYS Inc. ANSYS Workbench Version 11.0, Canonsburg, USA

16. EN 1991-1-2 (2002) Eurocode 1: actions on structures-part 1-2: general actions - actions on structures exposed to fire, European Standard, CEN, Brussels

17. Thomas G (2002) Thermal properties of gypsum plasterboards at high temperatures. Fire Mater 26:37-45

18. Källsner B, König J (2000) Thermal and mechanical properties of timber and some other materials used in light timber frame construction, paper CIB-W18/33-16-3, CIB Working Commission W18-Timber Structures, Delft, Netherlands 
19. Just A (2009) Full scale wall tests of timber frame assemblies, Test report, Tallinn, University of Technology

20. Versuchsbericht Nr. 210003433-1 (April 2004) Materialprüfanstalt Nordrhein-Westfalen

21. Frangi A, Erchinger C, Fontana M (2008) Charring model for timber frame floor assemblies with void cavities. Fire Saf J 43:551-564

22. Studhalter J (2007) Beurteilungsgrundlagen für die werkstoffoptimierten Bauteile Isover, Lignum-Dokumentation Brandschutz: Bauteile in Holz-Decken, Wände und Bekleidungen mit Feuerwiderstand

23. Just A, Schmid J, König J (2010) Failure times of gypsum plasterboards, Interflam 2010. In: Proceedings of the 12th international conference, 5 July 2010, Nottingham, UK 